\title{
EVALUASI KEPATUHAN PETUGAS DALAM TATALAKSANA PNEUMONIA DI KABUPATEN TOLITOLI
}

\author{
Abd Rahman ${ }^{1}$, Mohammad Hakimi², Rina Triasih ${ }^{3}$
}

\begin{abstract}
Background: The infant mortality rate in Central Sulawesi Province is 52 per 1000 live births, which is the fifth highest in Indonesia. The high rate of morbidity and mortality of acute respiratory infection and pneumonia in children under five in Tolitoli District in past year related to the implented efforts triands ARI eradication program. This is indeed related to how officers comply with pneumonia management correctly.

Objective: To evaluate officers' compliance in implementing pneumonia manager Tolitoli Distric.

Method: This was an observational study with cross-sectional study design, using quantitative approach, Data were collected through observation and interview using standardized questionnaire by tramed nurses. Officer who handled pneumonia program in Tolitoli District and those in Publich Health Centres were recruited as subjects.

Result and Discussion: One hundred and nineteen subjects were recruited to this study. The percentase of officers who complied with pneumonia management was $69 \%$. The result of multivariate analysis that was training increased officers' compliance in pneumonia management which was adjusted to education, knowledge and length of work had a significant relationship (PR: 1.79; $95 \% \mathrm{Cl}: 1,38-2,33$ ) and the increased value $\mathrm{R}^{2}$ of $6.3 \%$, it mean.

Conclusion: Trained officers were more compliant than untrained officers with the prevalence risk of 1.79 times. Education, knowledge, and length of working service were related to officers' compliance in pneumonia management.
\end{abstract}

Keywords: training, officers' compliance in pneumonia management

\begin{abstract}
ABSTRAK
Latar belakang: Angka kematian bayi di Propinsi Sulawesi Tengah sebesar 52 per 1000 kelahiran hidup dan menempati urutan kelima tertinggi di Indonesia. Tingginya angka kesakitan dan angka kematian balita akibat pneumonia di Kabupaten Tolitoli dalam beberapa tahun terakhir tidak terlepas dari seberapa jauh upaya program pemberantasan penyakit ISPA telah dilaksanakan. Hal ini sangat terkait dengan bagaimana kepatuhan petugas dalam melakukan tata laksana pneumonia secara tepat.

Tujuan: Diketahuinya kepatuhan petugas dalam melakukan tatalaksana pneumonia di Kabupaten Tolitoli. Metode: Penelitian ini merupakan jenis penelitian observasional dengan rancangan cross sectional dengan menggunakan pendekatan kuantitatif. Data dikumpulkan melalui observasi dan wawancara dengan subyek penelitian dengan menggunakan lembar observasi dan kuesioner.

Hasil dan Pembahasan: Sebanyak 119 subyek diikutkan dalam penelitian ini. Rata-rata petugas yang patuh terhadap tata laksana pneumonia sebesar $69 \%$. Hasil analisis multivariat menunjukkan bahwa variabel pelatihan dan kepatuhan petugas dalam tatalaksana pneumonia dengan mengikutsertakan variabel
\end{abstract}

\footnotetext{
Tolitoli Faculty of Medicine and Health Science

Maternal and Child Health-Reproductive Health Graduate Program, FK-UGM

Pediatric Department, Dr. Sardjito General Hospital, Yogyakarta
} 
pendidikan, pengetahuan dan masa kerja untuk dianalisis secara bersama mempunyai hubungan yang signifikan ((RP;1,79, IK 95\%; 1,38-2,33) dan peningkatan nilai R2 sebesar 6,3\%

Kesimpulan: Petugas yang telah dilatih lebih patuh dibanding petugas yang belum dilatih dengan risiko prevalensi 1,53 kali. Faktor pendidikan, pengetahuan dan masa kerja berhubungan secara bermakna dengan kepatuhan petugas dalam tataksana pneumonia.

Kata kunci: pelatihan, Kepatuhan petugas tatalaksana pneumonia

\section{PENDAHULUAN}

Penyakit Infeksi Saluran Pernafasan Akut (ISPA) khususnya pneumonia merupakan penyakit utama penyebab kesakitan dan kematian balita. Pneumonia menyebabkan 4 juta kematian pada anak balita di dunia dan merupakan $30 \%$ dari seluruh kematian yang ada. ${ }^{1} \mathrm{Di}$ negara-negara berkembang pneumonia merupakan penyebab kematian utama ${ }^{2}$ ISPA sendiri dijuluki sebagai pembunuh utama kematian bayi serta balita di Indonesia. Hal itu merujuk pada hasil Konferensi Internasional mengenai ISPA di Canberra Australia pada Juli 1997, yang menemukan empat juta bayi dan balita di negara-negara berkembang meninggal tiap tahun akibat ISPA.

Pelaksanaan program pemberantasan penyakit ISPA adalah bagian dari pembangunan kesehatan, dan merupakan upayayang mendukung peningkatan kualitas sumber daya manusia serta merupakan bagian dari upaya pemberantasan dan pencegahan penyakit menular. Pemberantasan penyakit ISPA di Indonesia dimulai pada tahun 1984, bersamaan dengan dilancarkannya pemberantasan penyakit ISPA di tingkat global oleh World Health Organization (WHO)

Angka kematian bayi di Indonesia sebesar 34 kematian per 1000 kelahiran hidup. Sementara di Propinsi Sulawesi Tengah angka kematian bayi sebesar 52 per 1000 kelahiran hidup. Angka ini masih cukup tinggi dibanding survei demografi kesehatan indonesia (SDKI) dan menempati urutan ke 5 tertinggi di Indonesia. Data kesehatan Propinsi Sulawesi Tengah menunjukkan bahwa ISPA menempati rangking teratas yaitu 53.170 kasus (27,58\%). Di Kabupaten Tolitoli target cakupan pneumonia tahun 2007 sebesar 94\% namun sebagian besar Puskesmas belum mencapai target.

Pengawasan yang intensif pada kegiatan program ISPA dapat memberikan hasil diagnosis dan perawatan ISPA yang tepat dan akurat. $^{3}$ Penelitian ini bertujuan melihat pengaruh pelatihan yang berkaitan dengan pneumonia baik yang telah dilatih maupun yang belum dilatih terhadap kepatuhan petugas dalam melakukan tatalaksana pneumonia. Mengingat ketrampilan petugas kesehatan merupakan indikator yang berdampak langsung terhadap balita sakit. ${ }^{4}$

\section{METODE}

Penelitian ini merupakan jenis penelitian observasional dengan rancangan cross sectional (potong lintang). ${ }^{5}$ Penelitian ini untuk mengetahui kepatuhan petugas kesehatan dalam melakukan tatalaksana pneumonia dengan pendekatan kuantitatif.

Penelitian ini dilaksanakan di Puskesmas dan Puskesmas Pembantu di wilayah kerja Dinas Kesehatan Kabupaten Tolitoli. Populasi dan subjek penelitian adalah petugas kesehatan (perawat dan bidan). Sampel diambil secara total populasi sebanyak 119 orang responden yang 
memberikan pelayanan pneumonia pada balita di unit rawat jalan Puskesmas dan Pustu.

Variabel terikat dalam penelitian ini adalah kepatuhan petugas dalam tata laksana pneumonia. Variabel bebas yaitu pelatihan dan variabel luar adalah umur, pengetahuan, pendidikan, masa kerja.

Data dikumpulkan dengan wawancara menggunakan kuesioner. Observasi juga dilakukan pada petugas yang melakukan pelayanan pneumonia dengan menggunakan lembar observasi tata laksana pneumonia. Standar kepatuhan ditentukan berdasarkan pengukuran mutu pelayanan kesehatan yang dilakukan dibagi dengan standar yang telah ditetapkan. ${ }^{6}$ Petugas dikatakan patuh bila standar kepatuhannya mencapai $\geq 76 \%$. Data dianalisis secara univariabel dengan distribusi frekuensi, bivariabel menggunakan uji chi-square dan multivariabel menggunakan uji regresi logistik.

\section{HASIL DAN PEMBAHASAN}

\section{Subjek Penelitian}

Sejumlah 119 perawat dan bidan diikutkan dalam penelitian ini, 44 subjek penelitian merupakan petugas puskesmas induk dan 75 subyek bertugas di Pustu. Tabel 1 menunjukkan karakteristik subjek penelitian. Proporsi umur petugas kesehatan lebih banyak pada umur $<40$ tahun yaitu sebesar 61 (52,3\%), tingkat pendidikan petugas sebagian besar berkategori tinggi sebanyak 67 (56,3\%) sedangkan tingkat pengetahuan petugas yang kurang terhadap tata laksana pneumonia yaitu sebesar 62 (52,1\%). Petugas yang mempunyai masa kerja $\geq 10$ tahun lebih banyak dibanding petugas yang mempunyai masa kerja $<10$ tahun yaitu sebesar $71(59,7 \%)$.
Tabel 1 . Distribusi Frekuensi karakteristik Subjek Penelitian

\begin{tabular}{lc}
\hline Karakteristik & n \% \\
Umur & \\
$\bullet<40$ tahun & $61(51,3)$ \\
$-\geq 40$ tahun & $58(48,7)$ \\
Pendidikan & \\
- Tinggi & $67(56,3)$ \\
- Rendah & $52(43,7)$ \\
Pengetahuan & \\
- Baik & $62(52,1)$ \\
- Kurang & $57(47,9)$ \\
Masa kerja & \\
- < 10 tahun & \\
- $\geq 10$ tahun & $48(40,3)$ \\
\hline
\end{tabular}

\section{a. Kepatuhan petugas}

Dari hasil observasi didapatkan kepatuhan petugas dapat digolongkan dalam dua kategori yaitu patuh dan tidak patuh dalam tatalaksana pneumonia. Sebagian besar (69\%) petugas kesehatan di Kabupaten Tolitoli memiliki kepatuhan dalam tata laksana pneumonia pada balita. Seperti terlihat pada gambar 1.

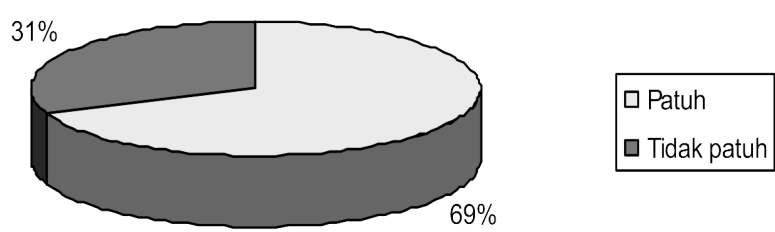

Gambar 1. Jumlah petugas kesehatan yang patuh dan tidak patuh dalam tata laksana pneumonia

\section{b. Pelatihan petugas}

Proporsi petugas yang telah mendapat pelatihan pneumonia sebesar 68 (57\%) dan yang belum mendapat pelatihan berjumlah 51 (43\%). Seperti pada gambar 2 dibawah ini. 

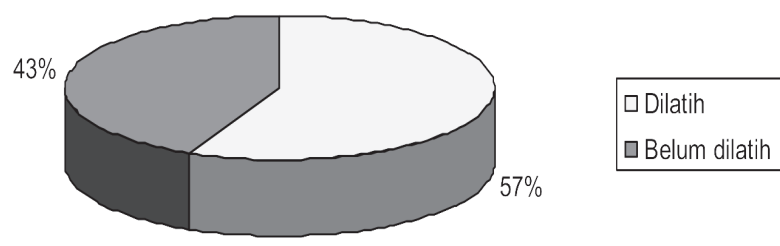

Gambar 2. Jumlah petugas kesehatan yang telah dilatih dan belum dilatih dalam tatalaksana pneumonia

Dari 68 petugas yang telah dilatih sebagian besar petugas $(72,1 \%)$ baru mendapat pelatihan 1 kali dan tidak ada yang mendapat pelatihan lebih dari 3 kali (Tabel 2).

Tabel 2. Frekuensi pelatihan

\begin{tabular}{lc}
\hline Frekuensi Pelatihan & $\mathbf{n}(\%)$ \\
\hline Satu kali & $49(72,1)$ \\
$2-3$ Kali & $19(27,9)$ \\
$>3$ kali & - \\
\hline Total & $68(100)$ \\
\hline
\end{tabular}

Dari 68 petugas yang telah dilatih, $67,6 \%$ mendapatkan pelatihan dalam waktu satu tahun yang lalu (Tabel 3)

Tabel 3. Waktu terakhir mendapat pelatihan

\begin{tabular}{lc}
\hline Waktu Pelatihan Terakhir & $\mathbf{n}(\%)$ \\
\hline$<1$ tahun & $46(67,6)$ \\
$1-5$ tahun & $22(32,4)$ \\
\hline Total & $68(100)$ \\
\hline
\end{tabular}

\section{Faktor-faktor yang berhubungan dengan kepatuhan petugas dalam tata laksana pneumonia}

Hasil analisis bivariabel hubungan pelatihan dengan kepatuhan petugas dalam tata laksana pneumonia dan variabel luar umur, pendidikan, pengetahuan dan masa kerja, Dapat dilihat pada tabel 4 berikut
Tabel 4. Faktor-faktor yang berhubungan dengan kepatuhan petugas dalam tata laksana pneumonia

\begin{tabular}{lcc}
\hline Faktor & RP & IK 95\% \\
\hline Pernah mendapat pelatihan & 1,53 & $1,15-2,03^{*}$ \\
Mendapat pelatihan $>1$ kali & 1,26 & $1,10-1,45^{*}$ \\
Pelatihan terakhir & 1,28 & $1,10-1,49^{*}$ \\
Umur $<40$ tahun & 1,16 & $0,90-1,47$ \\
Pendidikan tinggi & 1,34 & $1,03-1,75^{*}$ \\
Pengetahuan baik & 1,77 & $1,33-2,35^{*}$ \\
Masa kerja $\geq 10$ tahun & 1,37 & $1,04-1,82^{*}$ \\
\hline Keterangan:*= Signifikan & &
\end{tabular}

Dari tabel 4 diketahui pelatihan petugas memiliki hubungan yang signifikan dengan kepatuhan petugas dalam tatalaksana pneumonia $(\mathrm{RP}=1,53 \mathrm{IK} 95 \% 1,15-2,03)$. Artinya petugas yang telah dilatih lebih patuh 1,53 kali dibanding petugas yang belum dilatih.

Hasil analisis jumlah pelatihan yang diikuti dengan kepatuhan petugas dalam tata laksana pneumonia secara statistik signifikan. Dengan nilai ( $R P=1,26$ IK95\% 1,10 - 1,45) didapatkan petugas yang telah dilatih lebih dari satu kali mempunyai peluang 1,26 kali untuk patuh dalam tatalaksana pneumonia.

Analisis hubungan jarak pelatihan dengan penelitian dengan kepatuhan petugas dalam tata laksana pneumonia secara statistik signifikan dengan nilai ( $R P=1,28$ IK95\% 1,10 $1,49)$ didapatkan pada petugas yang mendapat pelatihan terakhir kurang dari 1 tahun dan mempunyai peluang 1,28 kali untuk lebih patuh dalam tatalaksana pneumonia.

Analisis umur dengan kepatuhan petugas dalam tata laksana pneumonia tidak mempunyai hubungan signifikan ( $R P=1,16$ IK95\% 0,90-1,48).

Hasil analisis pendidikan dengan kepatuhan petugas dalam tata laksana pneumonia menunjukkan hubungan signifikan. Nilai $\mathrm{RP}=1,34$ (IK95\% 1,10-1,45). Petugas yang berpendidikan tinggi mempunyai peluang 1,34 kali lebih patuh dibanding petugas yang berpendidikan rendah. 
Analisis pengetahuan dengan kepatuhan petugas dalam tata laksana pneumonia mempunyai hubungan yang signifikan. Petugas yang memiliki pengetahuan baik mempunyai peluang 1,77 kali lebih patuh dibanding petugas yang memiliki pengetahuan kurang (IK95\% 1,34 2,35).

Hasil analisis hubungan antara masa kerja dengan kepatuhan petugas dalam tata laksana pneumonia menunjukkan hubungan signifikan. Petugas yang mempunyai masa kerja $\geq 10$ tahun dan mempunyai peluang 1,38 kali lebih patuh dibanding petugas yang mempunyai masa kerja $<10$ tahun (IK95\% 1,04 - 1,82).

\section{Analisis Multivariabel}

Data variabel dalam penelitian ini telah dikategorikan dengan skala pengukuran kategorik, analisis multivariat menggunakan uji statistik dengan tahapan permodelan regresi binomial, tingkat kemaknaan $5 \%(p=0,05)$ dan tingkat kepercayaan 95\% (IK). Hasil analisis multivariat dapat dapat dilihat pada tabel 5 .

Tabel 5. Analisis Permodelan Regresi Logistik Evaluasi Kepatuhan Petugas Dalam Tatalaksana Pneumonia

\begin{tabular}{|c|c|c|c|c|}
\hline Variabel & $\begin{array}{c}\text { Model } 1 \\
\text { RP } \\
\text { (IK 95\%) }\end{array}$ & $\begin{array}{c}\text { Model } 2 \\
\text { RP } \\
\text { (IK 95\%) }\end{array}$ & $\begin{array}{c}\text { Model } 3 \\
\text { RP } \\
\text { (IK 95\%) }\end{array}$ & $\begin{array}{c}\text { Model } 4 \\
\text { RP } \\
\text { ( IK 95\%) }\end{array}$ \\
\hline $\begin{array}{l}\text { Pelatihan } \\
\text { Dilatih } \\
\text { Belum dilatih }\end{array}$ & $\begin{array}{c}1,53 \\
(1,15-2,03)^{*}\end{array}$ & $\begin{array}{c}1,72 \\
(1,31-2,26)^{*}\end{array}$ & $\begin{array}{c}1,69 \\
(1,29-2,20)^{*}\end{array}$ & $\begin{array}{c}1,79 \\
(1,38-2,33)^{*}\end{array}$ \\
\hline $\begin{array}{l}\text { Pendidikan } \\
\text { Tinggi } \\
\text { Rendah }\end{array}$ & & $\begin{array}{c}1,55 \\
(1,21-1,99)^{*}\end{array}$ & & $\begin{array}{c}1,40 \\
(1,12-1,74)^{*}\end{array}$ \\
\hline $\begin{array}{l}\text { Pengetahuan } \\
\text { Baik } \\
\text { Kurang }\end{array}$ & & & $\begin{array}{c}1,67 \\
(1,30-2,14)\end{array}$ & $\begin{array}{c}1,66 \\
(1,30-2,11)^{*}\end{array}$ \\
\hline $\begin{array}{l}\text { Masa kerja } \\
\geq 10 \text { tahun } \\
<10 \text { tahun }\end{array}$ & & & $\begin{array}{c}1,53 \\
(1,22-1,92)^{*}\end{array}$ & $\begin{array}{c}1,43 \\
(1,14-1,78)^{*}\end{array}$ \\
\hline N & 119 & 119 & 119 & 119 \\
\hline-2 log likelihood & 221.68 & 218.13 & 212.69 & 210.72 \\
\hline R2 & 0.0151 & 0.0308 & 0.0550 & 0.0638 \\
\hline
\end{tabular}

Keterangan:*= Signifikan

Model 1 untuk menjelaskan pelatihan dan kepatuhan petugas dalam tatalaksana pneumonia tanpa dilakukan adjusted dengan variabel lain. Hasil perhitungan statistik didapatkan bahwa petugas yang telah dilatih mempunyai peluang 1,53 kali lebih patuh dibanding petugas yang belum dilatih. Hasil ini menunjukkan ada perbedaan yang signifikan antara petugas yang telah dilatih dengan petugas yang belum dilatih. Nilai $R^{2}$ didapatkan sebesar 0,01 artinya pelatihan bagi petugas dapat meningkatkan kepatuhan tata laksana pneumonia sebesar 1 persen.

Model 2 dibangun untuk mengetahui kontribusi variabel pendidikan terhadap pelatihan 
dan kepatuhan petugas dalam tata laksana pneumonia. Analisis model ini menunjukkan adanya hubungan yang bermakna secara statistik maupun praktis antara pelatihan petugas dengan kepatuhan petugas dalam tata laksana pneumonia (RP 1,72; IK95\%: 1,31-2,26). Artinya petugas yang dilatih mempunyai kepatuhan 1,72 kali dibanding petugas yang belum dilatih setelah dikontrol pendidikan petugas. Hasil analisis model ini juga menunjukkan bahwa pendidikan petugas baik secara statistik maupun praktis meningkatkan kepatuhan petugas dalam tata laksana pneumonia 1,55 kali dengan nilai $(\mathrm{RP}=1,55 \mathrm{IK} 95 \% ; 1,21$ - 1,99). Berdasarkan nilai $R^{2}$ yang diperoleh, ternyata model ini dapat meningkatkan kepatuhan petugas sebesar 3 persen.

Model 3 dibangun untuk mengetahui kontribusi variabel pengetahuan dan masa kerja terhadap pelatihan dan kepatuhan petugas dalam tata laksana pneumonia. Pada model ini terlihat bahwa terdapat hubungan yang bermakna secara statistik maupun praktis antara pelatihan petugas dengan kepatuhan petugas dalam tatalaksana pneumonia setelah dikontrol variabel pengetahuan dan masa kerja (RP 1,69; IK $95 \% 1,29-2,20$ ). Artinya petugas yang dilatih mempunyai kepatuhan dalam tata laksana pneumonia pada balita 1,69 kali dibandingkan petugas yang belum dilatih. Hasil analisis model ini juga menunjukkan bahwa pengetahuan mempunyai hubungan dengan kepatuhan petugas dalam tata laksana pneumonia ( $\mathrm{RP}=1,67$ IK95\%; 1,30 - 2,14) dan masa kerja ( $R P=1,53$ IK95\%; $1,22-1,92)$. Nilai $R^{2}$ dalam model ini dapat berpeluang meningkatkan kepatuhan petugas dalam tatalaksana pneumonia sebesar $5 \%$.

Model 4 dibangun untuk mengetahui hubungan pelatihan dengan kepatuhan petugas dalam tata laksana pneumonia dengan mempertimbangkan besar konstribusi semua variabel yang diikut- sertakan dalam analisis tersebut. Variabelvariabel dalam model 4 adalah pelatihan, pendidikan, pengetahuan dan masa kerja. Pada model ini menunjukkan hubungan yang bermakna baik secara praktis maupun secara statistik antara pelatihan dengan kepatuhan petugas dalam tatalaksana pneumonia dimana (RP; 1,79 , IK 95\%; 1,38-2,33) secara statistik variabel pendidikanpun mempunyai hubungan terhadap kepatuhan petugas (RP;1,40 IK95\%;1,12-1,74), begitu juga dengan pengetahuan mempunyai peluang meningkatkan kepatuhan (RP;1,66 IK 95\%; 1,30-2,11) dan masa kerja menunjukkan hubungan yang bermakna terhadap kepatuhan petugas dalam tatalaksana pneumonia (RP;1,43 $95 \% \mathrm{Cl} ; 1,14-1,78)$. Nilai $\mathrm{R}^{2}$ dalam model ini dapat berpeluang meningkatkan kepatuhan petugas dalam tatalaksana pneumonia sebesar $6 \%$.

Dari hasil analisis tersebut, peneliti cenderung untuk memilih model 4 sebagai model terbaik yang menggambarkan pelatihan dan kepatuhan petugas dalam tata laksana pneumonia dengan mengikutsertakan variabel pendidikan, pengetahuan dan masa kerja. Keadekuatan dicerminkan dengan adanya peningkatan koefisien determinan $\left(R^{2}\right)$ sebesar 0,063 .

Hasil penelitian ini menunjukkan bahwa petugas kesehatan yang telah mendapat pelatihan program penanggulangan pneumoia lebih patuh dalam melakukan tata laksana pneumonia pada balita dibandingkan dengan petugas kesehatan yang belum dilatih. Penelitian sebelumnya menunjukkan bahwa pelatihan dasar dapat meningkatkan proporsi untuk dapat mengidentifikasi, mendiagnosis dan mengobati pneumonia sebesar 4,2 kali. ${ }^{3}$ Pelatihan dan penyegaran bagi petugas kesehatan merupakan cara yang paling tepat untuk meningkatkan kemampuan petugas kesehatan dalam tata laksana pneumonia. Dengan demikian petugas kesehatan sangat perlu mendapatkan pelatihan 
secara berkesinambungan karena perkembangan tehnologi semakin pesat khususnya bidang kesehatan. Diharapkan petugas menjadi lebih mahir dan tepat dalam melakukan tatalaksana pneumonia. Pelatihan dan penyegaran merupakan suatu cara yang paling efektif untuk meningkatkan keterampilan bagi petugas di samping itu sebagian besar petugas kesehatan yang telah dilatih dapat melakukan ketrampilan cukup baik apabila mempunyai motivasi dan semangat yang tinggi. ${ }^{7}$ Motivasi yaitu merupakan tingkah laku seseorang yang tidak dapat dilihat dan akan mempengaruhi kinerja bagi petugas. ${ }^{8}$ Pelatihan merupakan suatu cara membantu seseorang menampilkan kemampuan yang terbaik, memberikan kesempatan untuk belajar lewat proses penemuan, diskusi dan alih pengalaman serta pada saat yang sama mendapat peningkatan keterampilan, pengetahuan, motivasi dan rasa percaya diri. ${ }^{9}$ mengemukakan bahwa kepatuhan adalah ketaatan atau pasrah pada tujuan yang yang telah ditentukan. Kepatuhan merupakan suatu permasalahan bagi semua disiplin kesehatan, salah satunya pelayanan kesehatan rumah sakit. ${ }^{10}$ Menurut beberapa ahli spesialis, bukan hanya pasien yang tidak mentaati nasihat yang diberikan kepada mereka akan tetapi para petugas juga sering tidak taat dengan aturan dan nasihat dalam memberikan pelayanan kesehatan yang paling tidak baik kepada pasien.

Pendidikan petugas berhubungan dengan pelatihan terhadap kepatuhan petugas dalam melakukan tata laksana pneumonia. Hal ini dapat menjelaskan bahwa pendidikan sangat penting untuk meningkatkan kepatuhan seorang petugas karena semakin tinggi pendidikannya maka keterampilannya pun semakin meningkat. Tingkat pendidikan seseorang akan mempengaruhi peningkatan kemampuan pengetahuan dan keterampilan seorang petugas. ${ }^{11}$ Pendidikan tinggi bagi petugas kesehatan dapat mencerminkan suatu wawasan yang lebih luas, serta cenderung untuk melakukan ketrampilan yang lebih baik. ${ }^{12}$

Pengetahuan atau kognitif merupakan domain yang sangat penting bagi pembentukan perilaku seseorang, karena pengetahuan akan merangsang terjadinya perubahan sikap bahkan tindakan seseorang individu. ${ }^{14}$ Pengetahuan merupakan faktor mendasar yang harus dimiliki oleh seseorang untuk mengubah perilaku dan gaya hidupnya. ${ }^{15}$

Masa kerja petugas merupakan salah satu indikator yang berpengaruh terhadap kepatuhan dan keterampilan petugas dalam melakukan tindakan tata laksana pneumonia dan hal ini berdasarkan penelitian yang menunjukkan bahwa masa kerja berhubungan secara bermakna dengan pelatihan terhadap kepatuhan petugas dalam tata laksana pneumonia. Masa kerja dapat mempengaruhi peningkatan keterampilan seseorang karena semakin lama bekerja maka kemampuan dan keterampilannya semakin meningkat. ${ }^{16}$ Pengalaman termasuk variabel individu yang mempengaruhi perilaku kerja. ${ }^{17}$

\section{KESIMPULAN DAN SARAN}

Sebagian besar petugas kesehatan di Kabupaten Tolitoli mempunyai kepatuhan dalam tatalaksana pneumonia. Petugas yang mendapatkan pelatihan lebih patuh dalam tata laksana pneumonia dibanding petugas yang belum dilatih dengan peluang 1,53 kali lebih patuh. Faktor pendidikan, pengetahuan dan masa kerja berhubungan dengan kepatuhan petugas dalam melakukan tata laksana pneumonia.

\section{DAFTAR PUSTAKA}

1. Kanra G, Ceyha M, Treatment of Children with Bacterial Pneumonia. IPA Journal (INCH), 1997; vol.9 No.1

2. Ostapchuck M, Donna MR, Richard H, CommunityAcquired Pneumonia in Infants and Children. American Family Physician, 2004; Volume 70, No 5 september 1,2004 
3. Hadi, A, Management of acute respiratory infections by community health volunteers: experience of Bangladesh Rural Advancement Committee (BRAC). Bulletin of the World Health Organization 2003; 81;183-189

4. Amaral J, Leite JM, Cunha AJLA, Victora CG, Impact of IMCI health worker training on routinely collected child health indicators in Northeast Brazil, Oxford Journals: 2005 20(1):142-148.

5. Sastroasmoro dan Ismail, Dasar-dasar metodologi penelitian klinis, edisi ke-3, CV Sagung Seto. Jakarta, 2008

6. Donabedian, A. The Definition of Quality and Approaches To Its Assesment, Explorations in Quality assessment Monitoring, Health Administration Press, Michigan 1980, Volume 1,

7. Handoko TH, Manajemen personalia dan sumber daya manusia, edisi kedua, Yogyakarta, BPFE, 2001

8. Surjono A, Lestari ED, Tumbelaka AR, Nasibah, Kuswanto, Wibowo T, Studi pengembangan puskesmas model dalam implementasi manajemen terpadu balita sakit (MTBS), reprints of the CHNRL, 2000

9. Hanafi, Mamdun M, Manajemen, Yogyakarta, UPP AMP YPKN, 2003
10. Thomas $M$, Coaching for staff development, $A$ review of knowledge compliance and strategies to improve practice, J res nurs, 2005, 10(5):547-529

11. Smet,B,PsikologiKesehatan.PT.Gramediawidiasarana Indonesia. Jakarta, 1994

12. Notoatmodjo, S., Kresno, S., Tafal, Z., Pratomo, H., Sasongko, A., Hassan, A., Damayanti, R., Krianto, T., Hadi, N.E. \& Ayubi, D, Promosi kesehatan: teori dan aplikasi. Jakarta: Rineka Cipta, 2005

13. Fadil SW.M., Alrahman, S.M.A, Cousens, C., Bustreo, F., Shadoul, A., Farhoud, S, Integrated management of chilhood illnesses strategy: compliance with referral and follow-up recommendation in gezire State, Sudan. Bull World Health Organ, 2003 81(10)

14. Juanita, Perilaku masyarakat dalam pemanfaatan pelayanan kesehatan, Majalah kesehatan masyarakat, Jakarta, 1997, No 3

15. Simon-Morton, B.G, Green W.H, Gottlieb, H.H, Introduction to health education and health promotion, Waveland press inc USA, 1995

16. Muchlas, M, Perilaku Organisasi, Ed. 1. Yogyakarta: Gadjah Mada University Press, 2005

17. Gibson, L.J., Ivancevich, M.J., Donnelly, H.J., Konopaske, R, Organization Behavior, Structure, Processes. McGraw-Hill. 2003 